\title{
PENGEMBANGAN PRODUK GENSET ENERGI SURYA DAN ANGIN TERPADU BERBASIS QUALITY FUNCTION DEPLOYMENT
}

\author{
Oleh : \\ WENDY TRIADJI NUGROHO *)
}

\begin{abstract}
ABSTRAK
Daerah pesisir Indonesia memiliki potensi kecepatan angin dan sinar matahari yang berlimpah. Ini merupakan sumber energi terbarukan yang dapat dimanfaatkan menjadi energi listrik. Penelitian ini bertujuan untuk mengembangkan produk genset berbahan baku sinar matahari dan kecepatan angin portable berbasis QFD. Target yang ingin dicapai adalah membuat rancangan kualitas dari produk genset ini berdasarkan suara konsumen dan expert yang diperoleh dari wawancar dan pengisian kuisioner. Adapun sasaran dari penelitian ini adalah membantu pemerintah untuk menciptakan pemberdayaan energi yang mengarah pada kemandirian energi untuk masyarakat desa terpencil khususnya di daerah pesisir. Metode yang akan diterapkan adalah melakukan survei, mengadakan wawancara kepada pengguna genset untuk mengisi kuesioner, dan mendefinisikan harapan pengguna genset dengan metode $Q F D$. Kegiatan penelitian yang telah dilaksanakan adalah survei pelanggan, menentukan atribut genset portable, dan membuat house of quality yang sesuai dengan keinginan pengguna. Hasil atau luaran penelitian yang diharapkan adalah menghasilkan kriteria genset portable energi terbarukan yang sesuai dengan keinginan pengguna.
\end{abstract}

Kata Kunci : portabel, QFD, house of quality, expert

\section{PENDAHULUAN}

\section{Latar Belakang}

Indonesia sesungguhnya memiliki potensi energi surya cukup besar karena beriklim tropis. Namun, sebagai negara kepulauan, seringkali banyak awan, sehingga potensi setiap daerah tidak sama. Tenaga surya cocok digunakan untuk daerah terpencil, pulau-pulau kecil, atau juga pedesaan yang belum mempunyai jaringan listrik dari PLN. Sebagaimana diketahui, Indonesia ini luas, terdiri dari ribuan pulau. Ada sebagian masyarakat yang belum menikmati listrik. Rasio elektrifikasi di Indonesia masih sekitar 67 persen. Artinya, 33 persen rumah tangga belum menikmati listrik. Sebagian di antaranya itu berada di daerah-daerah yang terpencil. (Pikiran Rakyat On Line Rabu, 18 Apr, 2012 08:01:51 AM). Daya yang dapat dihasilkan oleh energi surya adalah 4,80 $\mathrm{kWh} / \mathrm{m}^{2} /$ hari. Sedangkan kapasitas terpasangnya adalah 12 MW. (Dadan K, 2008).

Pemanfaatan tenaga angin sebagai sumber energi di Indonesia bukan tidak mungkin dikembangkan lebih lanjut. Di tengah potensi angin melimpah di kawasan pesisir Indonesia, total kapasitas terpasang dalam sistem konversi energi angin saat ini kurang dari 800 kilowatt. Kecepatan angin di wilayah Indonesia umumnya di bawah 5,9 meter per detik yang secara ekonomi kurang layak untuk membangun pembangkit listrik. Namun, bukan berarti hal itu tidak bermanfaat. Potensi energi angin di Indonesia umumnya berkecepatan lebih dari 5 meter per detik (m/detik). Hasil pemetaan Lembaga Penerbangan dan Antariksa Nasional (Lapan) pada 120 lokasi menunjukkan, beberapa wilayah memiliki kecepatan angin di atas $5 \mathrm{~m} /$ detik, masing-masing Nusa Tenggara Timur, Nusa Tenggara Barat, Sulawesi Selatan, dan Pantai Selatan Jawa. Adapun kecepatan angin $4 \mathrm{~m} /$ detik hingga $5 \mathrm{~m} /$ detik tergolong berskala menengah dengan potensi kapasitas 10-100 kW. (Kompas GSA. 2012).

QFD merupakan metode perencanaan dan pengembangan produk secara terstruktur dan memungkinkan tim pengembangan mendefinisikan secara jelas kebutuhan dan harapan pelanggan, dan mengevaluasi kemampuan produk atau jasa secara sistematik untuk memenuhi kebutuhan dan harapan tersebut. Jadi QFD merupakan praktek perbaikan proses yang memungkinkan organisasi untuk memenuhi harapan pelanggan (Wahyu, 1999). Cohen (1995) menambahkan bahwa QFD dapat digunakan untuk menunjukkan dengan tepat masalahmasalah yang menjadi pertimbangan konsumen dalam memilih suatu produk sehingga dapat dipastikan bahwa produk yang dirancang dapat memenuhi harapan konsumen. Agar tujuan penerapan QFD dapat tercapai maka perusahaan harus melakukan wawancara secara personal dengan konsumen atau disebut dengan istilah voice of customer. Voice of customer ini dapat diperoleh dengan berbagai cara seperti melalui 
interview atau wawancara secara langsung, kuisioner, pengamatan, dan sebagainya.

Pengembangan genset yang berbahan baku energi terbarukan seperti sinar matahari dan kecepatan angin masih belum banyak dilakukan. Hal ini sangat disayangkan karena kita memiliki potensi yang cukup besar, terutama untuk daerah-daerah pantai dan pegunungan. Banyaknya daerah-daerah yang yang belum dapat dijangkau oleh PLN menjadikan genset portabel sebagai alternatif solusi yang layak dipetimbangkan. Dilatarbelakangi oleh hal-hal tersebut di atas, maka penelitian ini perlu dilakukan.

\section{Permasalahan}

Masalah yang ingin diteliti adalah menentukan faktor-faktor/atribut-atribut untuk mengembangkan genset energi surya dan angin terpadu yang portabel melalui metode QFD.

\section{Batasan Masalah}

Ruang lingkup penelitian adalah :

- waktu pengambilan data adalah antar bulan September hingga Desember 2012

- tim pakar (ekspert) dianggap dapat mewakili pendapat dari para ahli di bidang pengembangan genset dengan metode QFD

- pengisi kuesioner dianggap sudah mewakili masyarakat pengguna genset

- pengambilan data hanya dibatasi di daerah Jember kota dan Kecamatan Puger

\section{Tujuan Penelitian}

Tujuan yang ingin dicapai dalam penelitian ini adalah untuk menentukan faktorfaktor/atribut-atribut untuk mengembangkan genset energi surya dan angin terpadu yang portabel melalui metode QFD.

\section{METODOLOGI}

\section{Waktu dan Tempat Penelitian}

Penelitian dilaksanakan pada bulan September 2010 sampai dengan bulan Juli 2011. Sedangkan tempat penelitian adalah di Fakultas Teknik Sipil dan Mesin, Université de La Rochelle-Perancis.

\section{Bahan dan Alat}

Bahan yang digunakan adalah kuesioner dan perlengkapan ATK, sedangkan peralatan yang dipakai adalah program Excell dan QFD untuk mengolah data hasil wawancara dengan tim pakar dan masyarakat pengguna genset.

\section{Metode Pelaksanaan}

\subsection{Pengambilan data}

Data-data diperoleh dari wawancara dengan tim pakar dan masyarakat pengguna genset di daerah Jember kota dan Kecamatan Puger. Adapun kuesionernya meliputi Kuesioner Kebutuhan Pelanggan, Kuesioner Tingkat Kepentingan Atribut dan Kuesioner Kepuasan Pelanggan.

Pengambilan data melalui wawancara ditunjukkan oleh gambar 1 dan gambar2.

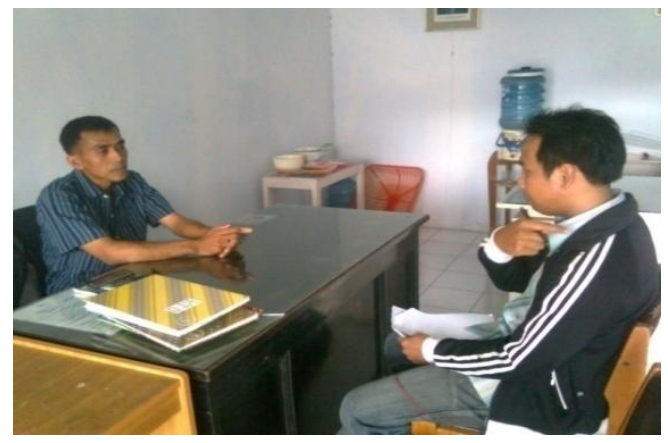

Gambar 1. Wawancara dengan pengguna genset

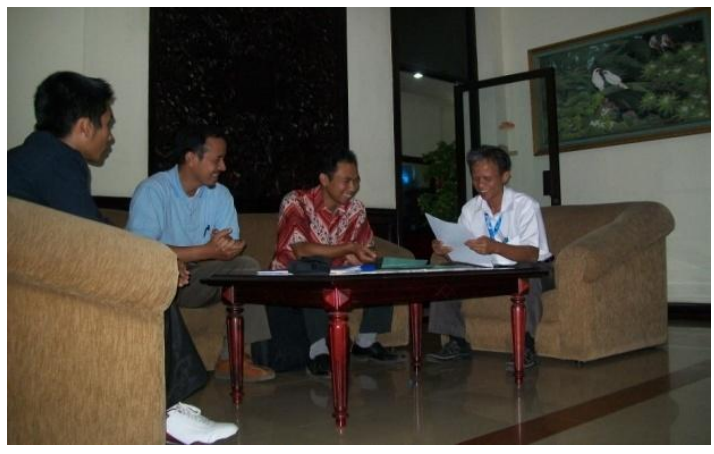

Gambar 2. Diskusi dengan Pakar

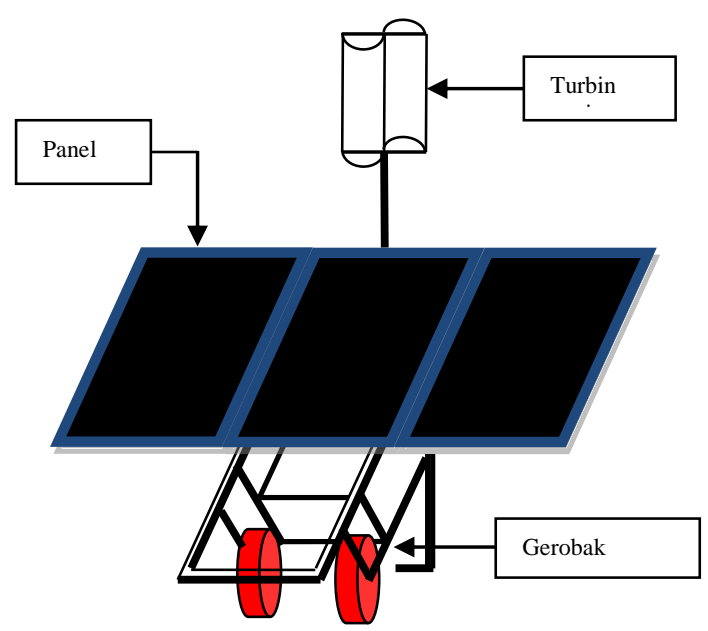

Gambar 3. Desain genset terpadu portable 
Wendy Triadji Nugroho, Pengembangan Produk Genset Energi Surya Dan Angin Terpadu Berbasis Quality Function Deployment

Gambar 3 merupakan desain generator angin dan surya terpadu yang dapat dipindah dengan mudah (portable). Generator ini yanga akan kita kembangkan karena memiliki kelebihan dapat memanfaatkan energi terbarukan (angin dan surya) serta dapat dipindah dengan mudah (panel surya dapat dilipat dan ada roda untuk memudahkan proses pemindahannya).

\subsection{Pengolahan data}

Data-data hasil pengukuran diolah dengan menggunakan Microsoft Excell dan QFD yang dibagi menjadi beberapa tahap yaitu :

- pengelompokan data yang berasal dari hasil wawancara

- mengolah data-data tersebut di Excell

- menginputkan hasil olahan data tersebut ke program QFD.

Adapun kuesioner-kuesioner yang digunakan, ditampilkan oleh gambar 3, gambar 4, dan gambar 5 di bawah ini.

\begin{tabular}{|c|c|c|c|}
\hline \multicolumn{4}{|c|}{ Campiranl, Kuesioner } \\
\hline \multicolumn{4}{|c|}{ 1. Kuesioner Kebutuhan Pelanggan } \\
\hline \multicolumn{4}{|c|}{ (Identifikasi Kebutuhan Pelanggan ) } \\
\hline \multicolumn{4}{|c|}{ Pengembangan Produk Genset Energi Surya Dan Angin Terpadu } \\
\hline \multicolumn{4}{|c|}{ Berbasis Quality Function Deployment } \\
\hline \multicolumn{4}{|c|}{ Jawablah pertanyaan di bawah ini dengan memberi tanda $(\mathrm{X})$ pada jawaban Anda! } \\
\hline \multicolumn{4}{|c|}{ 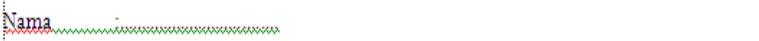 } \\
\hline \multicolumn{4}{|c|}{ 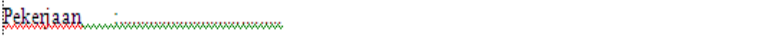 } \\
\hline $\mathrm{N}_{0}$. & Pertanyaan & \multicolumn{2}{|c|}{ Jawaban } \\
\hline 1 & $\begin{array}{l}\text { Apakah Fleksibilitas (dapat dipindah dengan mudah) menupakan atribut } \\
\text { dari produk genset yang Anda harapkan / Anda butuhkan? }\end{array}$ & YA & TIDAK \\
\hline 2 & $\begin{array}{l}\text { Apakah Estetika merupakan atribut dari produk gensetyang Anda harapkan } \\
\text { Anda butuhkan? }\end{array}$ & YA & TIDAK \\
\hline 3 & $\begin{array}{l}\text { Apakah Keamanan merupakan atribut dari produk genset yang Anda } \\
\text { harapkan Anda butuhkan? }\end{array}$ & YA & TIDAK \\
\hline 4 & $\begin{array}{l}\text { Apakah Pengoperasian merupakan atribut dari produk genset yang Anda } \\
\text { harapkan / Anda butuhkan? }\end{array}$ & YA & TIDAK \\
\hline 5 & $\begin{array}{l}\text { ApakahHarga merupakan atribut dari produk genset yang Anda harapkan } \\
\text { Anda butuhkan? }\end{array}$ & YA & TIDAK \\
\hline \multicolumn{4}{|c|}{$\begin{array}{l}\text { Catatan Penilaian: } \\
\text { Tawaban Ya diberi nilai } 3 \\
\text { Tawaban Tidak diberi nilai } 1 \\
\text { Tidak memilih diberi nilai } 2\end{array}$} \\
\hline
\end{tabular}

Gambar 3. Kuesioner Kebutuhan Pelanggan

\begin{tabular}{|c|c|c|c|c|}
\hline \multicolumn{5}{|c|}{ 2. Kuesiener Tingkat Kepentingan Atribut } \\
\hline \multicolumn{5}{|c|}{ Pekerjazn m n : } \\
\hline \multicolumn{5}{|c|}{$\begin{array}{l}\text { Jawablah pertanvan di bawah ini sesuai dengan tingkat kepentingan masing-masing atribut } \\
\text { broduk genset pada saat Anda mengounakan genset! }\end{array}$} \\
\hline \multicolumn{5}{|c|}{$\begin{array}{l}\text { 1. Seherapa pentingkah Fleksibilitas (dapat dipindah dengan mudab) mempengarubi Anda dalan } \\
\text { menggunakan produk genset? }\end{array}$} \\
\hline A. Sagngat Panting & B. Pentipg & C. Culkup Panting & D. Kurang Panting & E. Tidal Panting \\
\hline \multicolumn{5}{|c|}{ 2. Seberapa pentingkah Estetika mempengaruhi Anda dalam menggunakan produk genset? } \\
\hline A. Sargat Panting & B. Penting & C. Culkup Panting & D. Kurang Panting & E. Tidal Panting \\
\hline \multicolumn{5}{|c|}{ 3. Selerapa pentingkah Keamanan cetalsan menpengaruhi Anda dalam menggunalsan produl genset? } \\
\hline A. Sans pat Panting & B. Pentings & C. Culdup Penting & D. Kurang Panting & E. Tidalk Panting \\
\hline \multicolumn{5}{|c|}{ 4. Seherapa pentingkah Pengoperasian mempengarubi Anda dalam menggunalan produl genset? } \\
\hline A. Sang pat Penting & B. Pantings & C. Culkupreanting & D. Kurang Panting & E. Tidal-Panting \\
\hline \multicolumn{5}{|c|}{ 5. Seberapa pentingkah Harga mempengaruhi Anda dalam menggunalkan produk gula kelapa? } \\
\hline A. Sang sat Panting & B. Pentigng & C. Culkup Panting & D. Kuxang Panting & E. Tidal Panting \\
\hline $\begin{array}{l}\text { Catatan Penilaian } \\
\text { Jawaban sangat pe } \\
\text { Jawaban penting di } \\
\text { Jawaban culdup per } \\
\text { Jawaban kurang pe } \\
\text { Jwwaban tidal pent }\end{array}$ & $\begin{array}{l}\text { g diteri nila } \\
\text { anlai nilai } \\
\text { g diberi nila } \\
\text { g diberi nils } \\
\text { diteri nilai }\end{array}$ & & & \\
\hline
\end{tabular}

Gambar 4. Kuesioner Tingkat Kepentingan Atribut

\begin{tabular}{|c|c|c|c|c|}
\hline \multicolumn{5}{|c|}{ 3. Kuesioner Kepuasan Pelanggan } \\
\hline \multicolumn{5}{|c|}{ 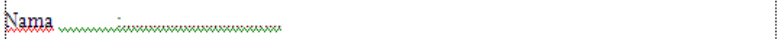 } \\
\hline \multicolumn{5}{|c|}{ 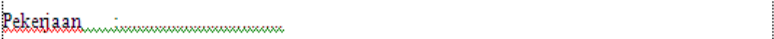 } \\
\hline \multirow{2}{*}{\multicolumn{5}{|c|}{$\begin{array}{l}\text { Jawablahpertanxaan di bawah ini sesuai dengan tingkat kepentingan masing-masing atribut } \\
\text { produl genset pada saat Anda mengrunakan genset! }\end{array}$}} \\
\hline & & & & \\
\hline \multicolumn{5}{|c|}{ 1. Apakah Anda puas dengan Fleksibilitas genset pada Produl yang ada? } \\
\hline A. Sangat Puas. & B. Puas & C. Culup Puas & D. Kurang Puas. & E. Tidak Puas \\
\hline \multicolumn{5}{|c|}{ 2. Apakah Anda puas dengan estetika genset pada Produk yang ada? } \\
\hline A. Sangat Puas & B. Puas & C. Culun Puas & D. Kurang Puas. & E. Tidak Puas \\
\hline \multicolumn{5}{|c|}{ 3. Apakah Anda puas dengan Keamanan cetakan gensetpada Produk yang ada? } \\
\hline A. Sangat Puas. & B. Puas & C. Culun Ruas & D. Kurang Puas & E. Tidal Puas \\
\hline \multicolumn{5}{|c|}{ 4. Apakah Anda puas dengan Pengoperasian gensetpada Produk yang ada? } \\
\hline A. Sangat Puas. & B. Puas & C. Cukup Ruas & D. Kurang Puas. & E. Tidak Puas \\
\hline \multicolumn{5}{|c|}{ 5. Apakah Anda puas dengan Harga genset pada Produk yang ada? } \\
\hline A. Sangat Puas & B. Puas & C. Cukun Puas. & D. Kurang Puas & E. Tidak Puas \\
\hline \multicolumn{5}{|l|}{ Catatan Penilaian: } \\
\hline \multicolumn{5}{|c|}{ Jawaban sangat puas diberi nilai 5} \\
\hline \multicolumn{5}{|c|}{ Iawaban puas diberi nilai nilai 4} \\
\hline \multicolumn{5}{|c|}{ Jawaban sukup puas diberi nilai 3} \\
\hline \multicolumn{5}{|c|}{ Jawaban kurang puas diberi nilai 2} \\
\hline \multicolumn{5}{|c|}{ Iawaban tidak puas diberi nilai 1} \\
\hline
\end{tabular}

Gambar 5. Kuesioner Kepuasan Pelanggan 


\section{DATA HASIL WAWANCARA DAN PEMBAHASAN}

\section{Data Hasil Wawancara}

Tabulasi hasil wawancara ditampilkan oleh tabel 1 dan tabel 2 sebagai berikut

Tabel 1. Frekuensi jawaban tingkat kepentingan atribut

\begin{tabular}{|c|c|c|c|c|c|}
\hline $\begin{array}{c}\text { Skowaba } \\
\mathrm{n}\end{array}$ & $\begin{array}{c}\text { Fleksibilit } \\
\text { as }\end{array}$ & $\begin{array}{c}\text { Estetik } \\
\text { a }\end{array}$ & $\begin{array}{c}\text { Keaman } \\
\text { an }\end{array}$ & $\begin{array}{c}\text { Pengoperasi } \\
\text { an }\end{array}$ & $\begin{array}{c}\text { Harg } \\
\text { a }\end{array}$ \\
\hline 5 & 17 & 7 & 21 & 7 & 11 \\
\hline 4 & 16 & 16 & 13 & 12 & 23 \\
\hline 3 & 2 & 12 & 1 & 16 & 1 \\
\hline 2 & 0 & 0 & 0 & 0 & 0 \\
\hline 1 & 0 & 0 & 0 & 0 & 0 \\
\hline $\begin{array}{c}\text { Jumla } \\
\text { h }\end{array}$ & 35 & 35 & 35 & 35 & 35 \\
\hline
\end{tabular}

Dari tabel 1 di atas dapat kita lihat bahwa keamanan menduduki tingkat teratas dalam kepentingan atribut karena memperoleh skor 5 dari 21 responden. Sedangkan yang mendapat skor terendah adalah pengoperasian dengan nilai 3 dari 16 responden.

Tabel 2. Frekuensi jawaban tingkat kepuasan pelanggan

\begin{tabular}{|c|c|c|c|c|c|}
\hline $\begin{array}{c}\text { Jawaba } \\
\mathrm{n}\end{array}$ & $\begin{array}{c}\text { Fleksibilit } \\
\text { as }\end{array}$ & $\begin{array}{c}\text { Estetik } \\
\text { a }\end{array}$ & $\begin{array}{c}\text { Keaman } \\
\text { an }\end{array}$ & $\begin{array}{c}\text { Pengoperasi } \\
\text { an }\end{array}$ & $\begin{array}{c}\text { Harg } \\
\text { a }\end{array}$ \\
\hline 5 & 9 & 8 & 5 & 5 & 2 \\
\hline 4 & 25 & 25 & 23 & 22 & 11 \\
\hline 3 & 1 & 2 & 7 & 8 & 21 \\
\hline 2 & 0 & 0 & 0 & 0 & 1 \\
\hline 1 & 0 & 0 & 0 & 0 & 0 \\
\hline $\begin{array}{c}\text { Jumla } \\
\text { h }\end{array}$ & 35 & 35 & 35 & 35 & 35 \\
\hline
\end{tabular}

Tabel 2 menunjukkan bahwa tingkat kepuasan pelanggan tertinggi ada pada fleksibilitas yang kemudian diikuti oleh estetika, harga, pengoperasian, dan keamanan.

\section{Pembahasan}

Uji validitas dan realibilitas kebutuhan pelanggan disajikan oleh tabel 3 dan 4 berikut ini
Tabel 3. Hasil Uji Validitas Kebutuhan Pelanggan

\begin{tabular}{|l|l|c|c|c|}
\hline No & Atribut & r_hitung & r_tabel & Keterangan \\
\hline 1 & Fleksibilitas & 0,488 & & Valid \\
\hline 2 & Estetika & 0,619 & \multirow{4}{*}{0,312} & Valid \\
\cline { 1 - 2 } & Keamanan & 0,511 & Valid \\
\hline 4 & Pengoperasian & 0,503 & & Valid \\
\hline 5 & Harga & 0,520 & & Valid \\
\hline
\end{tabular}

Dari tabel 2 dapat kita lihat bahwa kelima atribut kebutuhan pelanggan tersebut adalah valid sehingga dapat kita gunakan untuk tahap penelitian selanjutnya.

Tabel 4. Hasil Uji Realibilitas Kebutuhan Pelanggan

\begin{tabular}{|l|l|c|c|}
\hline No & $\begin{array}{l}\text { Atribut Kebutuhan } \\
\text { Pelanggan }\end{array}$ & $\begin{array}{c}\text { Corbach } \\
\text { Alpha }\end{array}$ & Keterangan \\
\hline 1 & Fleksibilitas & \multirow{5}{*}{0,623} & Reliabel \\
\hline 2 & Estetika & Reliabel \\
\hline 3 & Keamanan & & Reliabel \\
\hline 4 & Pengoperasian & & Reliabel \\
\hline 5 & Harga & & Reliabel \\
\hline
\end{tabular}

Dari hasil uji relibilitas dengan menggunakan program SPSS dapat kita ketahui bahwa berdasarkan informasi yang ditampilkan oleh tabel 4, kelima kebutuhan pelanggan tersebut adalah reliabel.

Berdasarkan hasil wawancara dengan pengguna dan pakar, didapatkan daftar persyaratan teknik yang dibutuhkan oleh pembuat genset. Persyaratan tersebut dapat dilihat pada tabel 5 sebagai berikut.

Tabel 5. Persyaratan teknik

\begin{tabular}{|c|c|c|}
\hline No & Atribut & Persyaratan Teknik \\
\hline 1 & Fleksibilitas & - Jumlah roda \\
\hline 2 & Estetika & - Bahan \\
\hline 3 & Keamanan & - $\quad$ Sistem mekanis \\
\hline 4 & Pengoperasian & - $\quad$ Manual/Otomatis \\
\hline 5 & Harga & - $\quad$ Daya beli masyarakat \\
\hline
\end{tabular}

Setiap persyaratan pelanggan diberikan peringkat berdasarkan tingkat kepentingan bagi pelanggan. Rating kepentingan berguna untuk memprioritaskan usaha dan pembuatan keputusan trade-off. Skala yang digunakan dalam tingkat kepentingan ini adalah skala likert lima angka. Tingkat kepentingan setiap persyaratan pelanggan 
Wendy Triadji Nugroho, Pengembangan Produk Genset Energi Surya Dan Angin Terpadu Berbasis Quality Function Deployment

diketahui melalui survey terhadap 35 pengguna generator dengan menggunakan kuesioner. Pelanggan diminta untuk mengurutkan dan memberikan peringkat pada masing-masing persyaratan pelanggan sesuai dengan tingkat kepentingan yang dirasakannya.Hasil survei tingkat kepentingan dianalisis menggunakan frekuensi jawaban dari 35 responden, di mana kriteria dari setiap tingkat kepentingan yang memiliki frekuensi terbanyak merupakan tingkat kepentingan suatu persyaratan pelanggan. Tingkat kepentingan pelanggan dapat dilihat pada tabel 6 sebagai berikut :

Tabel 6. Tingkat kepentingan atribut

\begin{tabular}{|c|l|c|}
\hline No & Atribut Generator "Portabel" & Kepentingan \\
\hline 1 & Fleksibilitas & 5 \\
\hline 2 & Estetika & 5 \\
\hline 3 & Keamanan & 5 \\
\hline 4 & Pengoperasian & 5 \\
\hline 5 & Harga & 4 \\
\hline
\end{tabular}

Survei pelanggan atau pengguna yang dilakukan untuk memperoleh voice of customer berlandaskan pada kuisioner yang terdiri dari :

1. Kuesioner Kebutuhan Pelanggan

2. Kuesioner Tingkat Kepentingan Atribut

3. Kuesioner Kepuasan Pelanggan

Selanjutnya tabulasi hasil respon pelanggan dinyatakan dalam tabel-tabel yang meliputi:

1. Data Kebutuhan Pelanggan

2. Data Tingkat Kepentingan Atribut

3. Data Kepuasan Pelanggan

Adapun frekuensi hasil jawaban responden disajikan di dalam 2 tabel (Tabel 1 dan Tabel 2) yang berisi:

1. Frekuensi Jawaban Tingkat Kepentingan Atribut

2. Frekuensi Jawaban Tingkat Kepuasan Pelanggan

Dari data-data tersebut di atas, maka dibuat House of Quality sebagaimana yang ditampilkan oleh gambar 6.

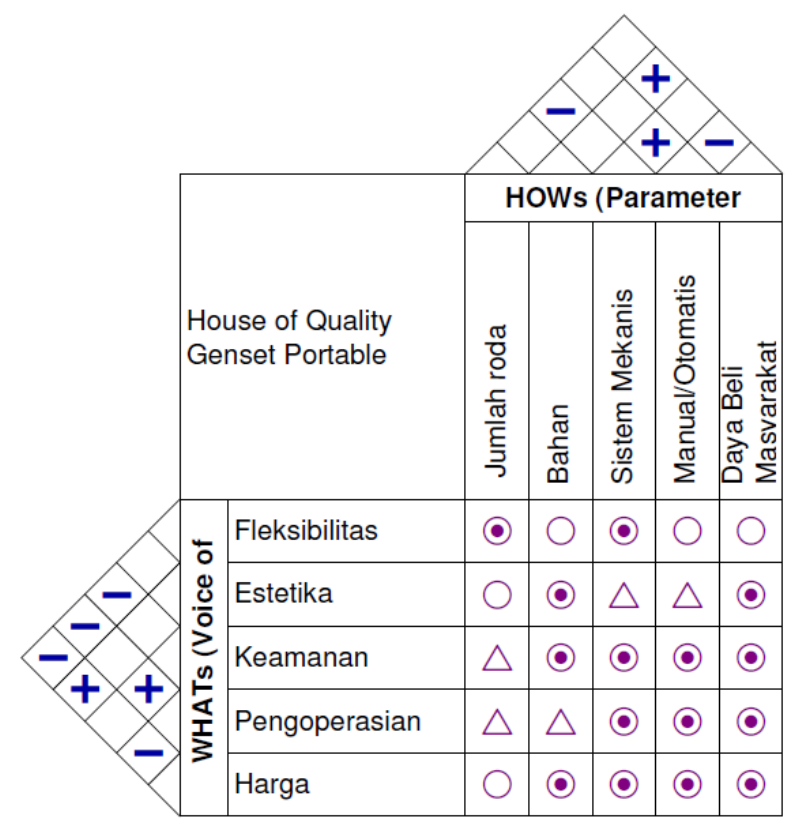

Gambar 6. House of Quality Genset Protable

Dengan mengacu pada penilaian hubungan antar atribut dapat kita lihat bahwa Harga dan Estetika serta Pengoperasian dan Keamanan memiliki hubungan yang sangat kuat. Demikian pula antar Bahan dan Daya Beli Masyarakat serta Sistem Mekanis dengan Manual/Otomatis. Sedangkan tingkat hubungan sedang ditunjukkan oleh Harga dengan Pengoperasian, Harga dengan Fleksibilitas, Jumlah Roda dengan Sisem Mekanis, dan seterusnya.

Adapun atribut-atribut WHATs dan HOWs memiliki tingkat hubungan sebagai berikut:

Tingkat hubungan kuat dinyatakan oleh : fleksibilitas dengan jumlah roda fleksibilitas dengan sistem mekanis estetika dengan daya beli masyarakat dan seterusnya

Tingkat hubungan sedang dinyatakan oleh : fleksibilitas dengan bahan fleksibilitas dengan manual/otomatis estetika dengan jumlah roda dan seterusnya

Tingkat hubungan lemah dinyatakan oleh estetika dengan sistem mekanis keamanan dengan jumlah roda harga dengan jumlah roda dan seterusnya

Dari korelasi-korelasi tersebut di atas, maka kita akan dapat menyusun skala prioritas. 


\section{KESIMPULAN DAN SARAN}

\section{Kesimpulan}

Berdasarkan hasil analisis dan pembahasan, maka kesimpulan dalam penelitian ini adalah sebagai berikut:

1. Atribut-atribut genset portabel yang dikehendaki oleh para pelanggan antara lain fleksibilitas, estetika, kamanan, pengoperasian, dan harga.

2. Persyaratan-persyaratan taknik yang dapat dipenuhi oleh perusahaan meliputi: jumlah roda, bahan, sistem mekanis, manual/otomatis dan dengan memperhatikan daya beli masyarakat.

3. Tingkat korelasi atribut-atribut yang termasuk di dalam WHATs dan HOWs menunjukkan variasi dari tidak ada hubungan, kuat, hingga sangat kuat.

4. Tingkat hubungan antara atribut-atribut di dalam WHATs dan HOWs menunjukkan variasi dari lemah, sedang, hingga kuat.

\section{Saran}

Kami berharap bahwa hasil penelian ini akan dapat dijadikan dasar untuk penelitian selanjutnya, yaitu untuk menentukan skala prioritas serta dimensi-dimensi genset portable yang lebih rinci. Oleh karena itu untuk persiapan tahap penelitian selanjutnya sebaiknya dilakukan:

a. Pembuatan kuesioner yang menyebutkan secara definitive tentang dimensidimensi genset portable

b. Mempertimbangkan unsure ergonomik dalam penyusunan kuesioner

c. Membuat House of Quality lebih kompleks untuk memudahkan pengembangan produk genset energi angin dan surya terpadu

\section{DAFTAR PUSTAKA}

Cohen, lou. 1995. Quality Function Deployment:How to Make QFD Work for You. Addison-Wesley Publishing Company. Massachusetsusa

Dadan Kusdiana. 2008. Kondisi Riil Kebutuhan Energi Di Indonesia Dan SumberSumber Energi Alternatif Terbarukan. Direktorat Jenderal Listrik Dan Pemanfaatan Energi Departemen Energi Dan Sumber Daya Mineral, Bogor.

Endang Widuri Asih. 2008. Perancangan Alat Pemecah Kedelai yang Ergonomis dengan Pendekatan Integrasi Model
Kano \& Quality Function Deployment. Jurnal Teknologi Technoscientia vol.1 No.2. Yogyakarta

Kompas GSA. 2012. Pengembangan Energi Angin Memungkinkan. Download 18 April 2012. http://www.energi.lipi.go.i d

Indra Permanahadi. 2008. Pembangkit Listrik Tenaga Angin. Download 18 April 2012. (http: / / renewableenergiindon esia/pembangkit-listriktenaga-angin/)

Nurul Iman Supardi dan Zuliantoni. 2008. Aplikasi QFD dalam Perancangan dan Pengembangan Produk. Prosiding Seminar Nasional Sains dan TeknologiII. Universitas Lampung

Parsaei, wg Sullivan (Eds.) 1993. Concurrent Engineering: Contemporary Issues and Modern Design Tools. Chapman and Hall. Melbourne

Persatuan Insinyur Mesin Indonesia. 2011. Energi Surya. Jurnal Insinyur Mesin. Download 18 April2010. (http://www.jurnalinsinyurmesin.com)

Sadono, M., G.T. Mulyati, dan W. Purwanto. 2000. Implementasi konsep Quality Function Deployment (QFD) untuk meningkatkan kualitas produk usaha bakery. Agritech 20(4) 
Wendy Triadji Nugroho, Pengembangan Produk Genset Energi Surya Dan Angin Terpadu Berbasis Quality Function Deployment 